\title{
Cyclin-Dependent Kinase 4 Inhibitor D
}

National Cancer Institute

\section{Source}

National Cancer Institute. Cyclin-Dependent Kinase 4 Inhibitor D. NCI Thesaurus. Code C122828.

Cyclin-dependent kinase 4 inhibitor D (166 aa, $\sim 18 \mathrm{kDa}$ ) is encoded by the human CDKN2D gene. This protein is involved in both cell cycle regulation and the inhibition of cyclin-dependent kinases. 